\title{
Особливості клініки та діагностики обтураційної непрохідності тонкої
}

\section{кИІІІи}

O. YU. IOFFE, H. V. BURENKO, M. M. STETS, V. M. PEREPADIA, O. A. POVCH

National Medical University by O. O. Bohomolets

\section{PECULIARITIES OF CLINIC AND DIAGNOSTICS OF OBTURATION OBSTRUCTION OF THE BOWEL}

Обтураційна непрохідність тонкої кишки належить до патології, що зустрічається рідко та не має суттєвої тенденції до зростання (А. В. Воробей, А. Ч. Шулейко, В. Н. Лурье, 2012). Відповідно, більшість наукових робіт із даної проблеми присвячена опису лише поодиноких випадків захворювання, без приділення належної уваги особливостям клінічного перебігу та питанням своєчасної діагностики захворювання (I. М. Дейкало, В. Я. Куц, 2009; О. П. Кургузов, 2007). Основними етіологічними чинниками даної патології виступають проростання пухлин органів черевної порожнини та заочеревинного простору в стінку кишки, безоари, жовчні конкременти, доброякісні та злоякісні пухлини тонкої кишки, гельміти. Нетиповість клінічної картини з відсутністю маніфестних проявів непрохідності кишечника зумовлює складність діагностики та накладає свій відбиток на термін проведення оперативного втручання, що принципово впливає на результати лікування зазначеної категорії хворих в цілому (А. Е. Войновский, Г. В. Азаров, Т. Г. Коляденкова, 2012; 3. М. Деметрашвили, Г. А. Асатиани, Г. Ш. Немсадзе, Г. З. Кончадзе, 2012). Вищевикладене зайвий раз підкреслює необхідність накопичення колективного досвіду з поглибленим аналізом кожного випадку захворювання $з$ метою вироблення алгоритму діагностично-лікувальних заходів при даній патології в подальшому.

Мета роботи: поліпшення результатів хірургічного лікування хворих з обтураційною непрохідністю тонкої кишки шляхом розробки алгоритму діагностичного моніторингу пацієнтів із даною патологією.

У роботі представлено результати лікування 17 хворих з обтураційною непрохідністю тонкої кишки, госпіталізованих до хірургічної клініки Київської міської клінічної лікарні № 3 за період із 2003 до 2013 року. Етіологічно причинами обтурації просвіту кишечника у 6 (35\%) пацієнтів було проростання пухлин товстої кишки та заочеревинного простору, у 5 (29\%) хворих - непрохідність, зумовлена фітобезоарами (шматочками кураги (№ 2), чорносливу, апельсиновою кіркою та квашеною капустою), у 4 (24 \%) пацієнток обтураційна непрохідність тонкої кишки була викликана жовчним конкрементом, у 2 (12\%) випадках - пухлинами тонкої кишки у вигляді карциноїду та лейоміосаркоми. Всі пацієнти при госпіталізації мали скарги на періодичний переймоподібний біль в черевній порожнині помірної інтенсивності при відсутності блювання, затримки відходження випорожнень та газів. Рентгенологічно при госпіталізації в жодному випадку не було переконливих даних за наявність кишкової непрохідності у вигляді чаш Клойбера та кишкових арок. Однак розпочаті консервативні заходи лікування у вигляді інфузійної спазмолітичної терапії, декомпресії проксимальних та дистальних відділів шлунково-кишкового тракту мали ефект лише в одному випадку. Після постановки сифонних клізм у пацієнта з калом відійшов фітобезоар у вигляді клубка квашеної капусти. Больовий синдром був купіруваний, стан хворого покращився. В решті спостережень консервативні заходи лікування не мали ефекту, що зумовило подальший діагностичний моніторинг у вигляді проведення ФГДС, ФКС, УЗД в динаміці та рентгенологічний контроль пасажу зависі сульфату барію по шлунково-кишковому тракту. В більшості випадків діагноз непрохідності кишечника було встановлено в подальшому на підставі даних інструментальних методів дослідження, а не клінічної картини захворювання. Оперативні втручання проведені в терміни від 2 до 5 діб з моменту госпіталізації. Об'єми операцій були такими: ентеротомія з видаленням жовчних конкрементів та фітобезоарів - у 7 випадках, резекція тонкої кишки з накладанням ентеро-ентороанасто- 
мозів “бік у бік” - у 4 випадках, виконання обхідної ентеро-ентеро- або ентероколостомії в 4 випадках, в одному спостереженні інтраопераційно вдалося проштовхнути фітобезоар до просвіту товстої кишки. Всі оперативні втручання завершені трансназальною інтубацією тонкої кишки. В післяопераційному періоді летальних випадків не було. Всі хворі виписані із стаціонару в терміни від 10 до 14 діб.

Аналізуючи результати лікування хворих із даною патологією, можна зазначити, що клінічна картина обтураційної непрохідності тонкої кишки не має типового перебігу і не завжди дає підстави для встановлення діагнозу. При цьому ретельно зібраний анамнез може наштовхнути хірурга на думку про характер патології при встановленні попереднього діагнозу. Ключовими факторами у встановленні діагнозу та визначенні показань до проведення оперативного втручання виступають дані інструментальних методів дослідження у вигляді гастростазу за результатами ФГДС та об'ємом і характером виділень по шлунковому зонду, дилатація петель тонкої кишки та маятникоподібні рухи останньої за даними УЗД, затримка евакуації кон- трастної речовини з порожнини шлунка, дилатація супрастенотичного відділу тонкої кишки з верифікацією рівня перешкоди за результатами барієвої проби. Відповідно, раннє включення до діагностичного моніторингу хворих із підозрою на обтураційну непрохідність тонкої кишки інструментальних методів дослідження дає можливість скоротити терміни встановлення діагнозу та своєчасно надати хворим адекватну хірургічну допомогу, що суттєвим чином зменшує ризик післяопераційних ускладнень та покращує результати лікування пацієнтів із даною патологією.

Висновки. 1. Обтураційна непрохідність тонкої кишки належить до патології, що рідко зустрічається та не має суттєвої тенденції до зростання.

2. Раннє залучення до діагностичного моніторингу інструментальних методів дослідження дає можливість скоротити терміни встановлення діагнозу та визначення показань до проведення оперативного втручання.

3. Своєчасність надання адекватної хірургічної допомоги є запорукою поліпшення результатів лікування хворих із даною патологією.

Отримано 30.01.13 